\title{
金属粉末射出成形における埋込み脱脂
}

河野 隆年的，佐々木英幸的，鎌田 公一汭

小原 康司敌，川原 業三舐

的岩手県工業試験場, $=020$ 岩手県紫波郡南村津志田.

吹岩手製鉄侏，广开024 北上市和賀町藤根 18 地割 14 .

\section{The Debinding Method with Burying Process on the Metal Injection Molding}

\author{
Takatoshi Kouno ${ }^{\text {ț } 1}$, Hideyuki Sasaki ${ }^{2} 1$, Kō-ichi Kamada \\ Yasuji Obara ${ }^{\Im 2}$ and Gyouzou Kawahara ${ }^{\precsim 2}$ \\ \$1 Industrial Research Institute of Iwate Prefecture, Tushida Tonan-mura Siwa Iwate 020. \\ 虹 Iwate Iron Co., Ltd., 18-14 Fujine Kitakami Iwate 024 .
}

Received June 24, 1991

\begin{abstract}
For shortening debinding times on the metal injection molding, the thermal debinding method with burying process was investigated. The powders made up by the mixture of reduced iron powder $(\overline{\mathrm{d}}: 70 \mu \mathrm{m})$, carbonyl iron powder $(\overline{\mathrm{d}}: 6.4 \mu \mathrm{m})$ and carbonyl nickel powder $(\overline{\mathrm{d}}: 9.3 \mu \mathrm{m})$ were used. The carbon powders ( $0.2 \mathrm{wt} \%)$ were used as the luburicant for the powders. And the montan wax and the polyethylene wax were used as binder. The green bodies buried in the zirconsand were debinded under heating from room tenperature to $450 \mathrm{r}$ in $\mathrm{N}_{2}$ flow $(0.5 \mathrm{z} / \mathrm{min})$. The debinding times were from 9 hour to 22 hour. Then the debound bodies were sintered at 1100,1180 and $1250 \mathrm{C}$ in $\mathrm{H}_{2}$ atomosphere with heating rate of $1000 \mathrm{t} / \mathrm{h}$.

As the results, about 90 wt\% binders were dibined and then the sintered parts at $1250 t$ showed the relative density of $80 \sim 87 \%$. the elongatione of $2 \sim 7 \%$. the tensil strength of $19 \sim$ $27 \mathrm{Kgf} / \mathrm{mm}^{2}$ and the hardness of $71 \sim 94(\mathrm{HRF})$.
\end{abstract}

\section{1 緒 言}

金属粉末射出成形法（MIM）は、ロストワックス、 金属粉末治金等につぐ金属加工法として出現し、その優 れた特性から、近年、急激な発展を続けている”。MI Mは、粉末治金に比へ $10 \mu \mathrm{m}$ 前後の金属粉末を使用す ることから、高価ではあるが、密度の高い、かつ、複雑 な三次元の製品製造を可能とする。しかし、この技術を 発展させるためには、粉末源料を低価格で製造すること、 約 80 時間以上も必要とするバインターの脱脂時間を短 縮すること等多くの技術開発が必要となっている2。
バインダーの脱脂は、常压、加圧、真空および超臨界 状態を利用するが大別して、加熱脱脂法と溶媒抽出脱脂 法があり、各方法に適したバインダー、装置が開発され 脱脂時間の短縮化や脱脂工程の改善が行われている。

特に、近年、溶媒抽出法による脱脂時間の短縮化に関 する検討が行われている゙、4)が、有機溶刘を使用するた め作業濖境、脱脂体の保形性等検討すべき課題もある。

一方、従来のプラスチック系バインダーを脱脂する場 合、温度上昇によるバインダーの流動性を利用し射出成 形体外にバインダーを流出吸収させ、脱脂工程を改善す 
る試みが行われているら゙。しかしワックスを主体とし、 かつ埋込み法による脱脂時間の短縮化の報告はない。

著者らは、ワックス系バインターーと平均粒径 $70 \mu \mathrm{m}$ 鉄粉を主体とする射出成形体をジルコンサンドに埋込む 加熱脱脂法により脱脂時間の短糖が可能か検討した。

その結果、 $9 \sim 22$ 時間の脱脂処理後、焼結昇温速度 $1000{ }^{\circ} \mathrm{C} /$ 時間、 $1250{ }^{\circ} \mathrm{C}$ での 1 時間保持による焼結の場 合、相対密度約 $80 \sim 87 \%$ 、伸び約 $2 \sim 7 \%$ および引 張強度約 $19 \sim 27 \mathrm{kgf} / \mathrm{mm}^{2}$ 等の性質を持つ燒結体を得 ることが出来たのでその経過について報告する。

\section{2 実䪵方法}

\section{2-1 コンバウンドおよひ試嵞片の作成}

金属原料粉は太平洋金属（株）製の平均粒径 $70 \mu \mathrm{m}$ 金属粉末治金用鉄粉（KI P $255 \mathrm{M}$ )、平均粒径 6.4 $\mu \mathrm{m}$ 鉄粉お よび平均粒径 $9.3 \mu \mathrm{m}$ カーボニルニッケル粉 を重量比で $60 ： 20 ： 20 ， 55 ： 25 ： 20$ および 40 : 20：20 の割合で混合しコンバウンド重量割合の 92 wt \% とした。またこれら混合原料のタップ密度 (タップ 回数: 500）は $3.88 、 3.95$ および 3.84 であった。

一方、バインダーは、モンタンワックス、ポリエチレ ン（PE）ワックスおよびカーボン粉をコンパウンドの 重量割合の 5.8 wt \% . 2 wt \% および 0.2 wt\% となる ように配合した。

コンパウンドの作成は、各配合割合の鉄粉とカーボン 粉をV型混合器 (入江商会 (侏製) で 1 時間以上混合し た後、 $150{ }^{\circ} \mathrm{C}$ で 15 分間以上溶融させたワックスに小量 づつ混入し均一混合した後、温度を $120{ }^{\circ} \mathrm{C}$ と、加圧 7

$\mathrm{Kgf} / \mathrm{cm}^{2}$ で約 1 時間混練した。この混練物を冷却粉䂶 しコンパウンドを作成した。また $70 \mu \mathrm{m}$ 鉄粉含有量の 多い顧に試料A，B，Cとした。

他方、射出成形試験片金型は粉末治金協会規定の金属 焼結体の引張り試験片寸法とした。また、射出成形機は

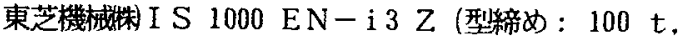
最大射出压： 4.1 t）を使用した。

\section{2-2 脱脂およひ㜔結方法}

脱脂は、各試験片を $100 \times 130 \times 160 \mathrm{~mm}$ の鉄製箱中 のジルコンサンドに埋込み盖をし、これをシリコニット 炉 (タバイ製作所製)に設置し、鉄製蓋の上部穴（径 5 $\mathrm{mm}$ ）上り窒素を每分 0.52 流しながら行った。22 時 間の脱脂パターンは、常温から $120{ }^{\circ} \mathrm{C}$ までを 1 時間で

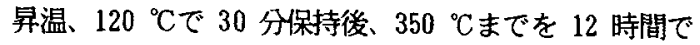
昇温、350 ${ }^{\circ} \mathrm{C} て ゙ 30$ 分保持後、 $450{ }^{\circ} \mathrm{C}$ までを 7 時間で昇

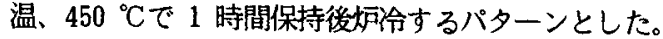

また、9 時間脱脂では更に $120{ }^{\circ} \mathrm{C} か ら の$ 各段階の加熱 時間を約 3 分の 1 縮めるパターンとした。

一方、焼結は脱脂後の試験片をアルミナ粉を敷いたコ ウ錰に移し、水素雾囲気中で昇温速度 $1000{ }^{\circ} \mathrm{C} /$ 時間. 最高温度を 1100.1180 および $1250{ }^{\circ} \mathrm{C}$ とし 1 時間保持

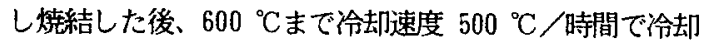
し、以後自然冷却した。

\section{3 結果および考察}

\section{3-1 コンバウンドの性状および熱重量変化}

A、B、C 3種類のコンパウンド試料をスクリュ一温 度 $140{ }^{\circ} \mathrm{C}$ で射出成形すると小さい粒径鉄羒の含有量の多 い試料Cほど成形性が良いが、スクリュ一温度を $150{ }^{\circ} \mathrm{C}$ とすると粗い粒子の多い試料Aでは鼻垂れ現象を起こし やすくなる。

次に、Fig.1 に窒素雾囲気での試料Cコンパウンドの 加熱重量变化の結果を示す。

この結果から、重量変化はポリエチレンの天井温度付 近で緩やかになるものの $430{ }^{\circ} \mathrm{C}$ 付近から急激に減少し. $470{ }^{\circ} \mathrm{C}$ 付近から増量することが分かる。

これより脱脂最高温度は $470{ }^{\circ} \mathrm{C}$ 以下とした。

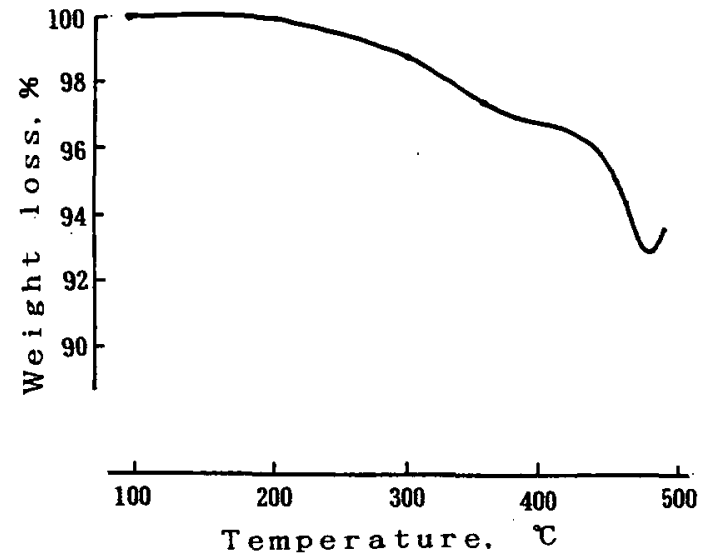

Fig. 1. Therwal decomposition of the injection molded compound

Heating Rate $: 5 \mathrm{c} / \mathrm{min}$

\section{3-2 バインダ一脱脂率}

9 時間の脱脂バターンによる結果をTable 1 に示す。 但し、試験片は、ラピットプレス（加西商工 (株) 製) の最大圧縮圧により、重量約 $15 \mathrm{~g}$ 、直径 1 インチの円 板とし、試験を行った。

Table 1 より脱脂率は、埋込み深さにより異なるが、 埋込み深さが $5 \mathrm{~cm}$ 以上では、約 $90 \sim 98 \%$ と高い脱 脂率を得ることが出来る。また、脱脂率は、埋込み深さ 
Table 1 The rate (wt\%) of thermal debinding with burying process used zironsand

\begin{tabular}{|c|c|c|c|c|}
\hline \multicolumn{2}{|c|}{ Burying depth } & SampleA & SampleB & SampleC \\
\hline 2 & $\mathrm{~cm}$ & 86.1 & 82.2 & 85.8 \\
\hline 5 & $\mathrm{~cm}$ & 92.7 & 88.2 & 95.9 \\
\hline 7 & $\mathrm{~cm}$ & 91.4 & 90.0 & 98.0 \\
\hline
\end{tabular}

が深いほと高く、かつ原料鉄粉のタッブ密度が高く、粗 い粒子の含有量が多いほど低くなる傾向にあることが分 かる。しかし、脱脂率か高くなるほどエッジの保形は亜 くなる。以下、本実験では埋め込み深さは、 $5 \mathrm{~cm}$ とした。 また、本法による脱脂試験片の色は、埋込み深さが深い 程黒くなる。これはワックスの多くが炭化されるためと 考える。

一方、従来脱脂時の敷粉、埋込み材として使われるア ルミナ粉では、膨れ、変形が生じ埋込み材としては不適 当であった。

次に、Photo. 1 に脱脂後の電子顕微鏡写真を示す。

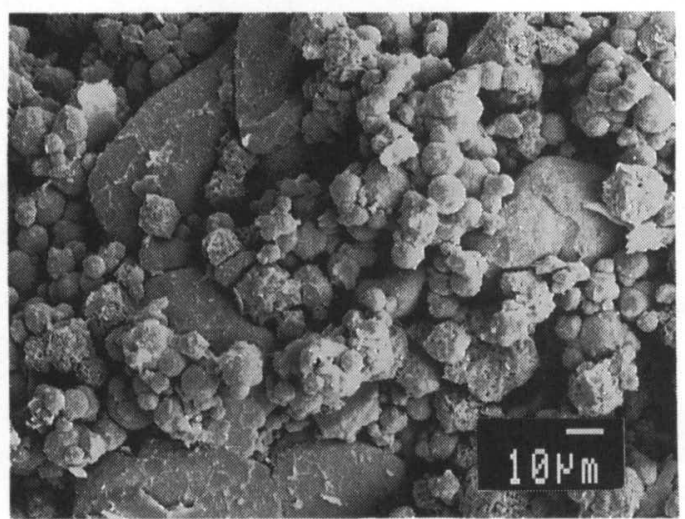

Photo. 1 The compound after debinding

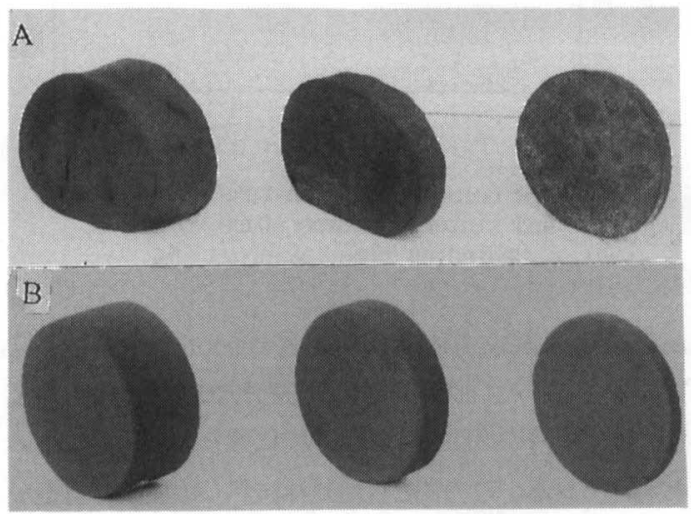

Photo. 2 Photograph of debound parts

A : Nonburying, B : Burying
写真は原料粉のみの混合状態とほぼ同じであり、バイン ダーのほとんどか除去されているのが分かる。

また、Photo. 2 に従来方法と本法による脱脂時の比較 写真を示す。従来法では、膨れ、変形が起こるが、本法 ではこのような現象はほとんどないことが分かる。

これは、加熱過程で成形体のワックスの多くがジルコ ンサンドに溶浸し、成形体に残存するワックス量が少な くなるためと考えられる。

\section{3-3 成形体に対する焼結体の收縮率}

Table 2 に射出成形体の最長部分を基準とした各温度で の焼結体の射出成形体に対する収縮率を示す。

Table 2 The rate $(\%)$ of linear shirnkage toword the injection molded compacts

\begin{tabular}{|cc|c|c|c|}
\hline \multicolumn{2}{|c|}{ Sinterd tempe } & SampeA & SampleB & SampleC \\
\hline $1100 \quad\left({ }^{\circ} \mathrm{C}\right)$ & 93.2 & 91.4 & 91.3 \\
& & 93.3 & 91.0 & 90.3 \\
\hline $1180 \quad\left({ }^{\circ} \mathrm{C}\right)$ & 91.6 & 90.3 & 88.2 \\
& & 91.9 & 90.4 & 88.1 \\
\hline \multirow{2}{*}{$1250 \quad\left({ }^{\circ} \mathrm{C}\right)$} & 90.7 & 89.2 & 86.4 \\
& & 90.5 & 89.8 & 87.2 \\
\hline
\end{tabular}

Upper:Debindinng time is 9 hour Lower:Debindinng time is 22 hour

Table 2 より焼結体の収縮率は、細かな金属粒子の含有 量が多く、焼結温度が高いほど大きいことが、また、脱 脂時間が 9 時間および 22 時間ともほぼ同じ值となるこ とが分かる。しかし、Sample B 1250 との值 89 \% は、 報告されている值6) より約 $5 \%$ 以上も小さくなっている。

一方、焼結体表面は、従来よりかなり粗くなる。

\section{$3-3$ 焼結体密度}

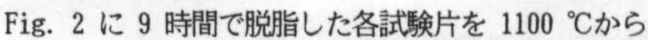
$1250{ }^{\circ} \mathrm{C} の$ 各温度で焼結した時の密度変化および相対密度 変化を示す。Fig. 2 上り焼結密度は、焼結温度が高く、 かつ、細かな金属粒子含有量が多い試験片ほと高い密度 となる。試験片Cの密度は、 $1250{ }^{\circ} \mathrm{C}$ 焼結温度で 7.02 となり、相対密度は、 87 \% となる。

一方、焼結昇温速度を毎時 $300{ }^{\circ} \mathrm{C}$ とすると $1250{ }^{\circ} \mathrm{C}$ の 保持では、各試験片とも $1000{ }^{\circ} \mathrm{C}$ 場合の密度の約 1.0 $3 \%$ 増しとなり、試験片Cの密度は 7.23 となる。この 值は、相対密度で約 $90 \%$ となる。他方、22 時間脱脂の 場合もほぼ同じ值となる。

但し、理論密度は 8.06 とし、測定は、アルキメデス法 によった。

次に、Photo. 3 に試料 B の焼結体組織電子顕微鏡写真 


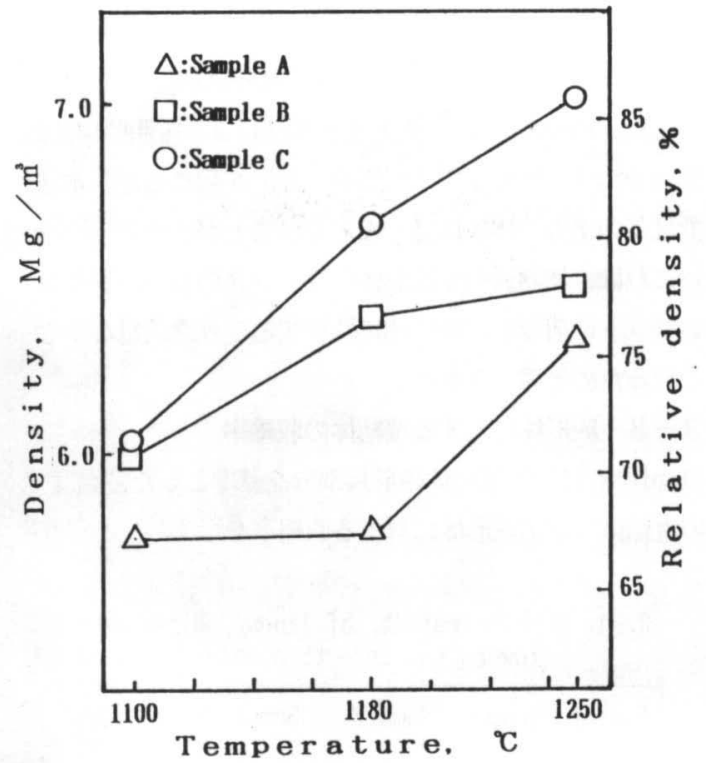

Fig. 2 The relation between density and sintering temperature of the injenction molded compacts Debinding time : $9 \mathrm{hr}$

を示す。写真から試料Bの焼結体では、組織が明確に表 れるが、試料A、Cの焼結体では、明確な組織は表れな かった。これは試料Bのタップ密度の影響と考えられる。 即ち、試料 A、Cは試料 Bに比べ空隙率が大きく焼結拡 散が実験温度では不十分なためであったと考えられる。

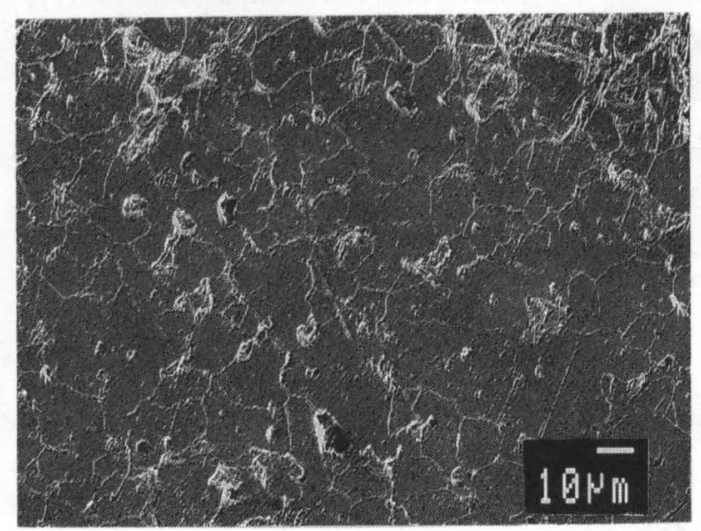

Photo. 3 The microstructure of sintered parts

\section{3-4 焼䊅体硬度}

Table 3 に各焼結温度での焼結体硬度 (HRF) を示 す。これより焼結硬度は、焼結温度か高く、かつ、細か な金属粒子含有量が多い試験片ほど高い硬度となる。ま た、各試験片とも脱脂時間が 9 時間 22 時間でもほほ同 じ值を示すことが分かる。試験片Cの場合、1250 ${ }^{\circ} \mathrm{C}$ の焼 結で硬度約 90 （HRF）となる。
Table 3 The hardness (HRF) on the sintered parts

\begin{tabular}{|c|c|c|c|}
\hline Sinterd tempe & Sampe A & Sample B & Sample C \\
\hline $1100 \quad\left({ }^{\circ} \mathrm{C}\right)$ & $\begin{array}{l}68.8 \\
69.4\end{array}$ & $\begin{array}{l}71.7 \\
69.4\end{array}$ & $\begin{array}{l}74.9 \\
72.3\end{array}$ \\
\hline $1180 \quad\left({ }^{\circ} \mathrm{C}\right)$ & $\begin{array}{l}66.8 \\
68.9\end{array}$ & $\begin{array}{l}71.8 \\
72.1\end{array}$ & $\begin{array}{l}76.9 \\
72.1\end{array}$ \\
\hline $1250 \quad\left({ }^{\circ} \mathrm{C}\right)$ & $\begin{array}{l}71.8 \\
76.6\end{array}$ & $\begin{array}{l}82.1 \\
87.6\end{array}$ & $\begin{array}{l}94.2 \\
82.0\end{array}$ \\
\hline
\end{tabular}

Indication refer. to Table 2

\section{3-5 引張り強度およひ伸び}

Fig. 3 に各試験片の各温度での焼結体の引張り強度試 験結果を示す。Fig. 3 の結果から引張り強度は、焼結温 度か高く、かつ、粗い金属粒子含有量の多いほど大きく なる傾向を示す。

このことは、Fig. 3 の焼結密度の变化から考えると、粒 径の大きく異なる金属粉による焼結体の場合、密度の大 きさと引張り強度は相関しない。この原因として、埋め

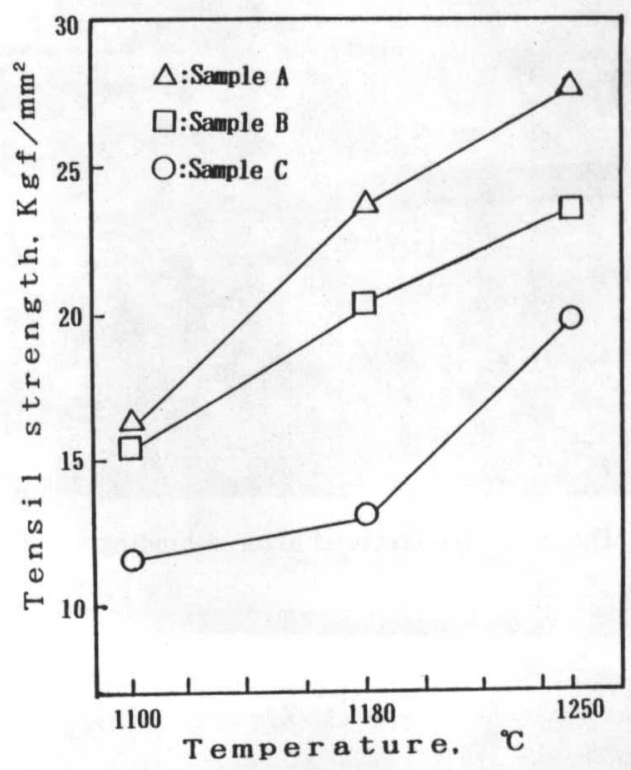

Fig. 3 The relation between tensile strength and sintering temperature Debinding time : $9 \mathrm{hr}$

込み脱脂の場合、細かな粒子径粉を多く含む成形体では、 空腙が多く、焼結時の最初に微細粒子による拡散が始ま るため、ワックスの炭化物が系内に残りやすくなるため と考えられる。このことは焼結体試料Cの炭素含有量が、 $\mathrm{A}, \mathrm{B}$ 試料の $0.54 \%$ に比べ $0.70 \%$ と高く、また、硬度 が 92.4 (HRF) と最も高いことから推察できる。 
他方、異なる粒径から構成されるコンパウンドの場合、 引張り強度は、粒径の大きい粒子同士の焼結状態に影響 されると推測される。即ち、粒径の大きな粒子同士の焼 結が進む注ど弓張り強度は大きくなると考えられる。

次に、Table 4 に各焼結試験片の伸乙試験結果を示す。

Table 4 The rate (\%) of elongation on the sinterd parts

\begin{tabular}{|c|c|c|c|}
\hline Sinterd tempe & Sampe A & Sample B & SampleC \\
\hline $1100 \quad\left({ }^{\circ} \mathrm{C}\right)$ & $\begin{array}{l}1.5 \\
1.8\end{array}$ & $\begin{array}{l}1.3 \\
1.7\end{array}$ & $\begin{array}{l}0.5 \\
0.3\end{array}$ \\
\hline $1180 \quad\left({ }^{\circ} \mathrm{C}\right)$ & $\begin{array}{l}4.6 \\
4.3\end{array}$ & $\begin{array}{l}3.7 \\
4.1\end{array}$ & $\begin{array}{l}1.2 \\
1.2\end{array}$ \\
\hline $1250 \quad\left({ }^{\circ} \mathrm{C}\right)$ & $\begin{array}{l}6.2 \\
6.7\end{array}$ & $\begin{array}{l}4.0 \\
7.0\end{array}$ & $\begin{array}{l}2.0 \\
4.0\end{array}$ \\
\hline
\end{tabular}

Indication refer. to Table 2

Table 4 より弓張り胎度と同様に焼結温度か高く、かつ 粗い金属粒子含有量の多いほど大きくなる傾向を示すが、 この原因は、引張り強度の場合と同じ理由によると考え られる。

\section{4 結 言}

M I M工程の脱脂時間を短縮するため、ワックスおよ び平均粒径 $70 \mu \mathrm{m}$ の鉄粉を主体とするコウンパウンド を用い、粉末治金拹会規定の金属焼結体の引張り試祫片 を成形し、埋込み法による脱脂時間の短縮化を検討した 結果、以下のような結果を得た。

（1）埋込みによりワックスの多くは埋入み込にに溶漫 するため、高い加熱速度でも脰れや变形等を防ぐ脱脂が 可能となる。

（2）埋込み、高速加熱脱脂の場合、多くのワックス
は、埋込み材および脱脂体中で炭化される。

（3）埋込み材をジルコンサンドとし、埋込み梁さを $5 \mathrm{~cm}$ 以上とすることにより、22 時間および 9 時間の 短い脱脂時間でワックスの脱脂率を約 $90 \%$ とすること が可能となる。

(4) 平均粒径 $70 \mu \mathrm{m}$ 鉄粉 $60 \mathrm{wt} \%$ ，平均粒径 6.4 $\mu \mathrm{m}$ 鉄粉 20 wt \% および平均粒径 $9.3 \mu \mathrm{m}$ 二ッケル粉 20 wt \% の混合原料とワックス系によるコンパウンドを 用いた試験片を 9 時間脱脂処理後、焼結昇温速度 1000 ${ }^{\circ} \mathrm{C} /$ 時間、 $1250{ }^{\circ} \mathrm{C} 1$ 時間保持により、相対密度約 7 $8 \sim 87 \%$ 、张強度約 $20 \sim 28 \mathrm{kgf} / \mathrm{mm}^{2}$ 、伸乙約 2 $\sim 7 \%$ 硬度約 72 (HRF) の機械的性質が得らる。

（5）上述の焼結昇温速度を $300{ }^{\circ} \mathrm{C} /$ 時間とすること により、相対密度を約 $90 \%$ とすることが可能となる。

以上本法は、短時間でバインターを岸化除去する機構 により金属粉末治金製品と $10 \mu \mathrm{m}$ 以下の粒子による金 属粉末射出成形製品の中間クラスの機械的性質をもつ製 品製造を可能にする。

\section{文献}

1）木村 尚：成形加工， $2,2(1990) 97$

2) James D. Destefani : Advance Mater. Process

$$
\text { 134. } 3(1988) 71
$$

$3)$ S.T.Lin, R.M.German : pmi, 21, 5 (1989) 21

4）斉藤，金子，井上：粉体粉末治金協会講演概要集 平成元年度春期大会 (1990) 126

5）浦岡，金子、岩崎, 寒川. 斉藤 ：

粉体およひ粉末金属. 37. 2(1990) 187

6）伊藤恒宏 ： 金属 $5 \underline{59}, 5(1989) 64$ 